\title{
Gamma-hexalactone flavoring causes DNA lesion and modulates cytokines secretion at non-cytotoxic concentrations
}

\author{
Luísa Zuravski ${ }^{*}$, Taiane A. Escobar ${ }^{1}$, Elizandra G. Schmitt², Queila D. F. Amaral ${ }^{3}$, Fávero R. Paula ${ }^{2,3}$, Thiago Duarte ${ }^{4}$,
} Marta M. M. F. Duarte, ${ }^{5}$ Michel M. Machado ${ }^{2,3}$, Luís F. S. Oliveira ${ }^{2,3}$ and Vanusa Manfredini ${ }^{1,2}$

From 2nd Latin American Congress of Clinical and Laboratorial Toxicology

Porto Alegre, Brazil. 3-6 June 2018

\begin{abstract}
Background: The $\gamma$-hexalactone is a flavoring agent for alcoholic beverages, teas, breads, dairy products, coffees, buttery products among others. It presents low molecular weight and exhibits sweet fruity aroma with nuances of nuts. As far as we know, both literature and government regulations have gaps regarding the safe use of the $\gamma$ hexalactone. In this context, the main objective of this work was to evaluate the effects of $\gamma$-hexalactone through in silico and in vitro approaches.

Methods: The in silico analysis was performed through four free online platforms (admetSAR, Osiris Property Explorer, pkCSM platform and PreADMET) and consisted of comparative structural analysis with substances present in databases. The computational prediction was performed in the sense of complement and guide the in vitro tests. Regarding in vitro investigations, screening of cytotoxicity (assessed by cell proliferation and viability parameters) in lymphocytes exposed to $\gamma$-hexalactone for $72 \mathrm{~h}$ were carried out previously to determine noncytotoxic concentrations. Following this screening, concentrations of 5.15, 0.515, and $0.0515 \mu \mathrm{M}$ were selected for the study of the respective potentials: genotoxic (assessed by DNA comet assay), chromosomal mutation (analysis of micronucleus frequency) and immunomodulatory (cytokine quantification using ELISA immunoassay). The results of in vitro assays were compared by one-way analysis of variance (ANOVA), followed by Bonferroni's post hoc test, conducted by statistic software.

Results: The platform PreADMET pointed out that $\gamma$-hexalactone is potentially mutagenic and carcinogenic. The comet assay data corroborate with these results demonstrating that $\gamma$-hexalactone at $5.15 \mu \mathrm{M}$ caused lymphocytes DNA damage. In relation to cytokine secretion, the results indicate that lymphocytes were activated by $\gamma^{-}$ hexalactone at non-cytotoxic concentrations, involving an increase in the IL-1 levels in all tested concentrations, ranging from approximately 56 to $93 \%$. The $\gamma$-hexalactone only at $5.15 \mu \mathrm{M}$ induced increase in the levels of IL-6 ( $60 \%)$, TNF-a $(\sim 68 \%)$ and IFN- $\gamma(\sim 29 \%)$, but decreased IL-10 ( 46\%) in comparison with the negative control $(p<$ 0.05). No change was observed in total lymphocytes or in cell viability at the concentrations tested.
\end{abstract}

Conclusions: In summary, the $\gamma$-hexalactone demonstrated immunomodulatory and genotoxic effects at noncytotoxic concentrations in healthy lymphocytes.

Keywords: Flavoring, y-Hexalactone, Lymphocytes, In silico, In vitro

\footnotetext{
* Correspondence: luisazuravski@unipampa.edu.br

'Programa de Pós-Graduação em Bioquímica, Universidade Federal do

Pampa, Uruguaiana, Brazil

Full list of author information is available at the end of the article
}

(c) The Author(s). 2019 Open Access This article is distributed under the terms of the Creative Commons Attribution 4.0 International License (http://creativecommons.org/licenses/by/4.0/), which permits unrestricted use, distribution, and reproduction in any medium, provided you give appropriate credit to the original author(s) and the source, provide a link to the Creative Commons license, and indicate if changes were made. The Creative Commons Public Domain Dedication waiver (http://creativecommons.org/publicdomain/zero/1.0/) applies to the data made available in this article, unless otherwise stated. 


\section{Background}

The $\gamma$-hexalactone improves the aroma and/or flavor of various food preparations such as alcoholic beverages, teas, breads, dairy products, coffees, buttery products among others [1]. Moreover, it is suitable to be used as fragrances in personal care (perfumes, creams, etc.) and household products [2].

The Food and Drug Administration (FDA) approved the $\gamma$-hexalactone for food use and the Council of Europe included it at a level of $10 \mathrm{ppm}(10 \mu \mathrm{g} / \mathrm{mL})$ in the list of artificial flavoring substances that may be added temporarily to foodstuffs without hazard to public health [1]. Moreover, Joint Food and Agriculture Organization (FAO) of the United Nations/World Health Organization (WHO) Expert Committee on Food Additives (JECFA) recommends the human safe intake threshold is $1800 \mu \mathrm{g} /$ person/day [3].

However, the true or real human exposure to $\gamma$ hexalactone is difficult to predict, because there is no complete information regarding the of its use and the differs way exposure. In addition, toxicological activities such as cytotoxicity and mutagenicity risk are not well known. In this context, this study aimed to evaluate the $\gamma$ hexalactone effects through computational and in vitro toxicological approaches.

\section{Materials and methods Chemicals}

$\gamma$-Hexalactone (CAS number 695-06-7), histopaque$1077^{\circ}$ and reagents for cell culture, including RPMI 1640 medium, fetal bovine serum (FBS), penicillin/streptomycin, phytohemagglutinin-M (PHA-M) were purchased from Sigma-Aldrich (St. Louis, MO, USA). All other chemicals were of analytical grade and obtained from standard commercial suppliers.

\section{In silico toxic risk prediction}

Four online computer programs were employed to estimate the possible toxicity risks of $\gamma$ - hexalactone: admetSAR server [4], Osiris Property Explorer [5], pkCSM platform [6] and PreADMET [7]. The mutagenicity and carcinogenicity effects were interpreted and expressed as "yes" or "no" and "not-detected" risk.

\section{In vitro toxicological assays}

\section{Peripheral blood mononuclear cells (PBMC) purification}

Whole fresh human blood $(20 \mathrm{~mL})$ was collected (ethics protocol in Universidade Federal do Pampa $n^{\circ} 27$, 045,614.0.0000.5323) into heparinized vacutainers by venipuncture from healthy adult volunteers $\quad n=3$; 20-35-year-old, non-smokers, nonalcohol consuming and not undergoing any medication). Briefly, fresh blood was transferred to conical centrifuge vials containing Histopaque-1077 density gradient centrifugation (1:1). The conical tube was centrifuged for $30 \mathrm{~min}$ at $400 \times \mathrm{g}$ and
PBMC were positioned in the interface. The opaque interface containing PBMC was carefully aspirated and then transferred into a clean conical centrifuge tube. The cells were washed by adding phosphate buffered saline (PBS) and centrifuged at $250 \times \mathrm{g}$ for $10 \mathrm{~min}$. The pellet was resuspended with RPMI 1640 medium. The cell viability using trypan blue dye exclusion method and cell count were assessed in a Neubauer's hemocytometer under optical microscopy. The PBMC suspension presented viability of $98 \%$. All the experiments were performed in triplicate.

\section{Lymphocytes culture}

A cell suspension comprising $10^{6}$ PBMC was cultivated in RPMI 1640 culture medium supplemented with $10 \%$ FBS, penicillin $(100 \mathrm{U} / \mathrm{mL})$, and streptomycin $(100 \mathrm{mg} /$ $\mathrm{mL}$ ). PHA-M at $1 \mathrm{mg} / \mathrm{mL}$ was added to stimulate the human peripheral blood lymphocytes. Negative control in all the experiments consisting of lymphocytes suspended in RPMI-1640 medium and the positive control contained $2.12 \mu \mathrm{M}$ bleomycin. Both were processed in the same way as the treatment cultures, but without $\gamma$ hexalactone. All assays were performed in triplicate from independent experiments.

\section{Cytotoxicity screening}

The concentrations selection for the present study was based on initial cytotoxicity screening. For this, human lymphocytes were exposed to $\gamma$-hexalactone at a range of concentrations $(876.12 \mu \mathrm{M}-0.087612 \mu \mathrm{M})$ and incubated at $37^{\circ} \mathrm{C}$ in $5 \% \mathrm{CO}_{2}$ for $72 \mathrm{~h}$, as described in a previous work by our group [8]. After this period, total lymphocytes were counted in a Neubauer's hemocytometer and $\mathrm{IC}_{50}$ (50\% cell-growth inhibition) values were calculated by a nonlinear regression method (data not shown). Following the initial screening, the concentrations 5.15, 0.515 and $0.0515 \mu \mathrm{M}$, which represent values of $\mathrm{IC}_{50 / 10}, \mathrm{IC}_{50 / 100}$, and $\mathrm{IC}_{50 / 1000}$ respectively, were used for studying the toxicological profile of $\gamma$-hexalactone in lymphocytes. According to $\mathrm{FAO} / \mathrm{WHO}$ [9] 10 to $20 \%$ of the intake amount can reach the bloodstream, so the range of concentrations tested in our study may represent actual values of exposure to this flavoring.

\section{Cellular proliferation assay}

The cell culture was previously evaluated using a Neubauer's hemocytometer [8]. The total cells count was performed, and the results were presented as total lymphocytes per culture flask.

\section{Cellular viability assay}

The cytotoxicity analysis was performed by trypan blue dye exclusion method [10] which is based on the loss of the integrity of the cell membrane. In this method, 
briefly, $25 \mu \mathrm{L}$ lymphocyte's cultures were exposed to trypan blue dye $(0.4 \% \mathrm{w} / \mathrm{v})$ and, after $3 \mathrm{~min}$, an aliquot was placed in a Neubauer chamber under a microscope at a magnification of $400 \times$ for the differential analysis. The viable cells are impermeable to the dye whereas non-viable cells, due to the formation of pores in the membrane, are permeable to the dye and thus exhibit a blue color. The results are presented as the percentage of living cells (i.e., those not stained with trypan blue) [11-13].

\section{Micronucleus test}

The micronucleus test was performed according to the technique described by Schmid [14]. After the incubation period, the lymphocytes suspension was harvested for slide preparation. The slides were stained with rapid commercial hematologic staining (New Prove, Brazil), analyzed by at least two different individuals who were blinded to the conditions and the mean of the two evaluators was used. For each slide, 200 lymphocytes were scored and classified according to absence or presence of the micronuclei.

\section{Comet assay}

The comet assay was performed according to Singh et al. [15]. After the incubation period, the lymphocytes were suspended in low-melting-point agarose and spread onto a glass microscope slide. Dry slides were incubated in ice-cold lysis solution $(2.5 \mathrm{M} \mathrm{NaCl}, 100 \mathrm{mM}$ EDTA, $10 \mathrm{mM}$ Tris, pH 10.0 and $1 \%$ Triton X-100 with $10 \%$ DMSO). After lysis, slides were placed on a horizontal electrophoresis unit, covered with a fresh solution (300 $\mathrm{mM} \mathrm{NaOH}$ and $1 \mathrm{mM}$ EDTA, $\mathrm{pH}>13$ ). Electrophoresis was performed for $20 \mathrm{~min}(25 \mathrm{~V} ; 300 \mathrm{~mA})$. Slides were then neutralized, washed, and stained with $0.1 \% \mathrm{AgNO}_{3}$. Slides were analyzed using an optical microscope. One hundred cells from each of the three replicate slides were analyzed by at least two different individuals who were blinded to the conditions. Cells were visually scored according to tail length and receive scores from 0 (no migration) to 4 (maximal migration) according to tail length. Therefore, the damage index for cells ranged from 0 (all cells with no migration) to 400 (all cells with maximal migration).

\section{Cytokines quantifications}

The levels of the cytokines IL-1, IL-6, TNF- $\alpha$, IFN- $\gamma$ and IL-10 were measured in cell-free supernatants using ELISA immunoassay kits according to the manufacturer's instructions (Neogen do Brasil, Indaiatuba, SP, Brazil) [16]. The results were expressed as cytokine unit measures $(\mathrm{pg} / \mathrm{mL})$.

\section{Statistical analysis}

$\mathrm{IC}_{50}$ was calculated employing nonlinear regression in GraphPad Prism 7 software [17]. For all other assays, the Gaussian distribution was verified by the KolmogorovSmirnov test. After that, significant differences were determined using one-way analysis of variance (ANOVA) followed by Bonferroni's post hoc conducted by the same software. The results were expressed as mean $\pm \mathrm{SD}$ and $p<0.05$ was considered as statistically significant.

\section{Results}

In silico toxic risk prediction

According to PreADMET program (Table 1) the $\gamma$ hexalactone presents potential mutagenic and carcinogenic.

\section{In vitro toxicological analyses \\ Cellular proliferation assay}

The total number of cells after exposure to noncytotoxic concentrations of $\gamma$-hexalactone remained like the negative control group (Fig. 1a).

\section{Cellular viability assay}

The lymphocytes showed viability greater than $96 \%$, after exposure to $\gamma$-hexalactone at non-cytotoxic concentrations for $72 \mathrm{~h}$ (Fig. 1b).

\section{Micronucleus test}

Figure 2a reports that $\gamma$-hexalactone did not induce micronucleus formation under the experimental conditions and concentrations assayed in human lymphocytes culture, when compared with the negative control $(p<0.05)$.

\section{Comet assay}

The Fig. 2b shows that $\gamma$-hexalactone at $5.15 \mu \mathrm{M}$, induced a DNA damage in the cultured lymphocytes reaching $71.43 \%$ higher than negative control $(p<0.05)$.

\section{Cytokine quantification}

Figure 3 shows the cytokine levels from the cultured lymphocytes exposure to non-cytotoxic concentrations of $\gamma$-hexalactone. This additive significantly increased the IL-1 levels in all tested concentrations, ranging from

Table 1 Toxicity risk prediction for the $\gamma$-hexalactone from the computer simulation

\begin{tabular}{|c|c|c|}
\hline \multirow[t]{2}{*}{ ID substance } & \multicolumn{2}{|c|}{$\begin{array}{l}\text { Toxic risk by admetSAR }{ }^{1} \text {; Osiris Property Explorer }{ }^{2} \text {, } \\
\text { pkCSM }^{3} \text {; PreADMET }{ }^{4} \text {; }\end{array}$} \\
\hline & Mutagenic & Carcinogenic* \\
\hline y-hexalactone & $\begin{array}{l}\text { Not Detected }^{1} \\
\text { Not Detected }^{2} \\
\text { Not Detected }^{3} \\
\text { Yes }^{4}\end{array}$ & $\begin{array}{l}\text { Not Detected }{ }^{1} \\
\text { Not Detected }{ }^{2} \\
\text { Yes }^{4}\end{array}$ \\
\hline
\end{tabular}

The toxic risks assessed, mutagenicity and carcinogenicity side effects were interpreted and expressed as "Yes" or "No" and "Not Detected" risk. *The pkCSM platform does not evaluate the carcinogenicity parameter. The superscripted numbers identify the platform used in the predictions 

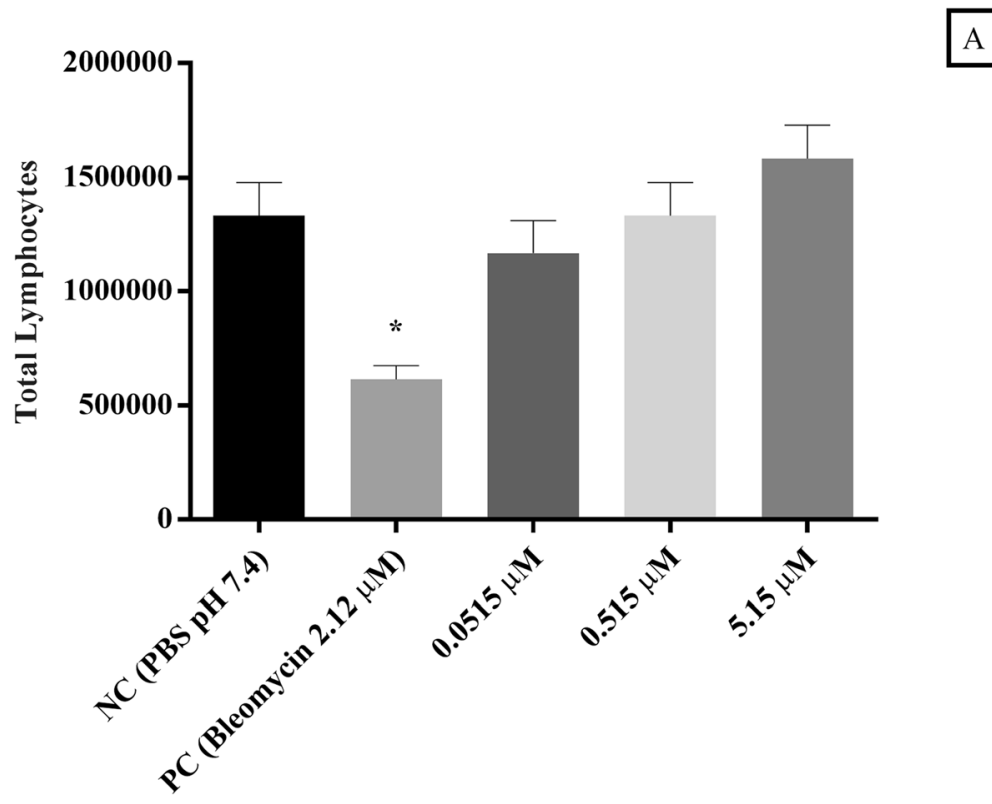

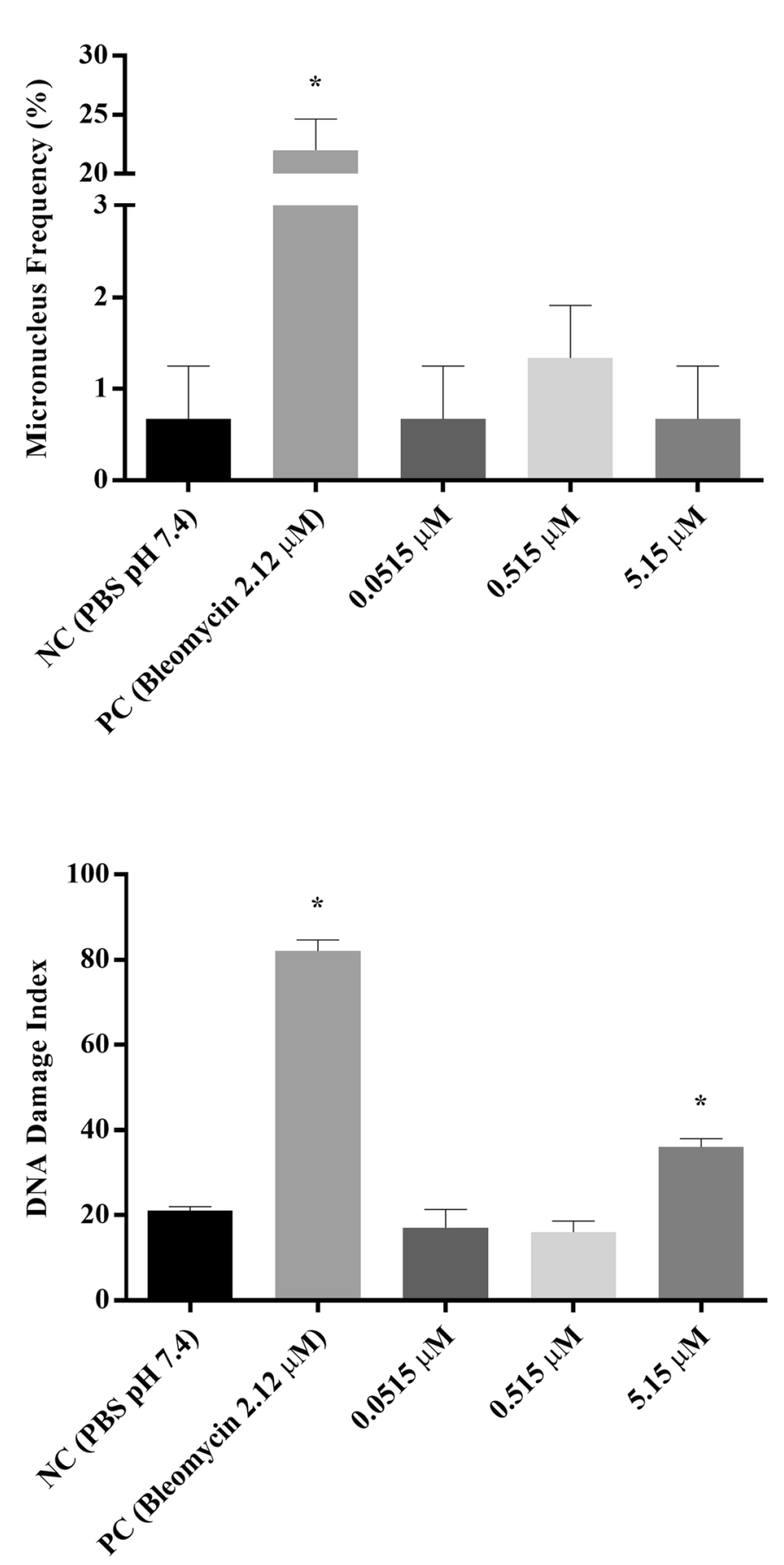

Fig. 2 Micronucleus frequency and DNA damage index in cultured lymphocytes ( $\mathbf{a}$ and $\mathbf{b}$ ) exposed to different concentrations of $\boldsymbol{\gamma}$-hexalactone. Data were expressed as mean \pm standard deviation, $n=3$, and analyzed by one-way analysis of variance (ANOVA) followed by Bonferroni's post hoc; $\left(^{*}\right)$ represent a statistically significant difference at $p<0.05$ in relation to the negative control (NC)

assess the compounds effects or its toxicity using accurate molecular comparisons with different endogenous molecular targets. In vitro tests try to reproduce an environment to mimic a realistic cellular exposure to compounds of interest, including the parameters as concentration range and exposure time [18]. Although these limitations exist, the in silico methodology has shown to be relevant to delineate studies and to serve as a method to explain the phenomena of the mechanisms of action. Moreover, in silico evaluations are advantageous for the rapid execution, low cost, and the ability to reduce the animal use in toxicity testing [19]. 

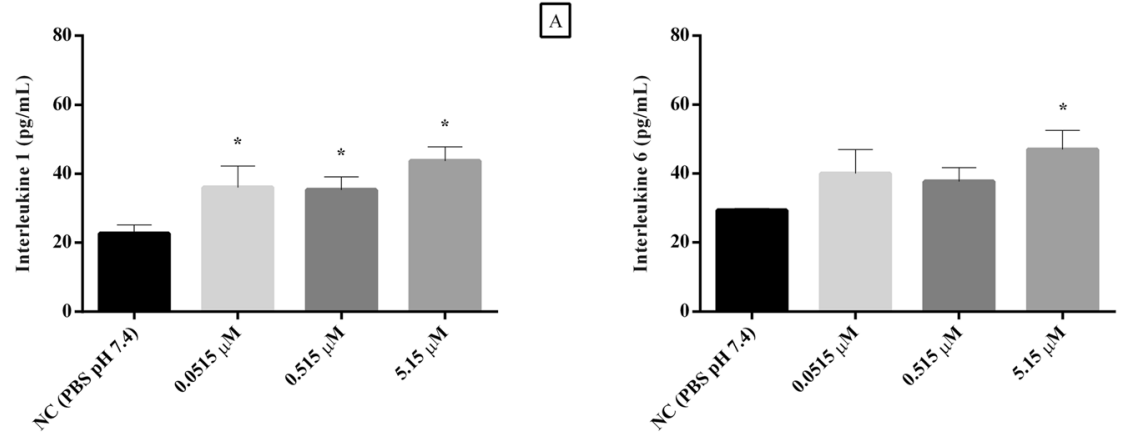

目
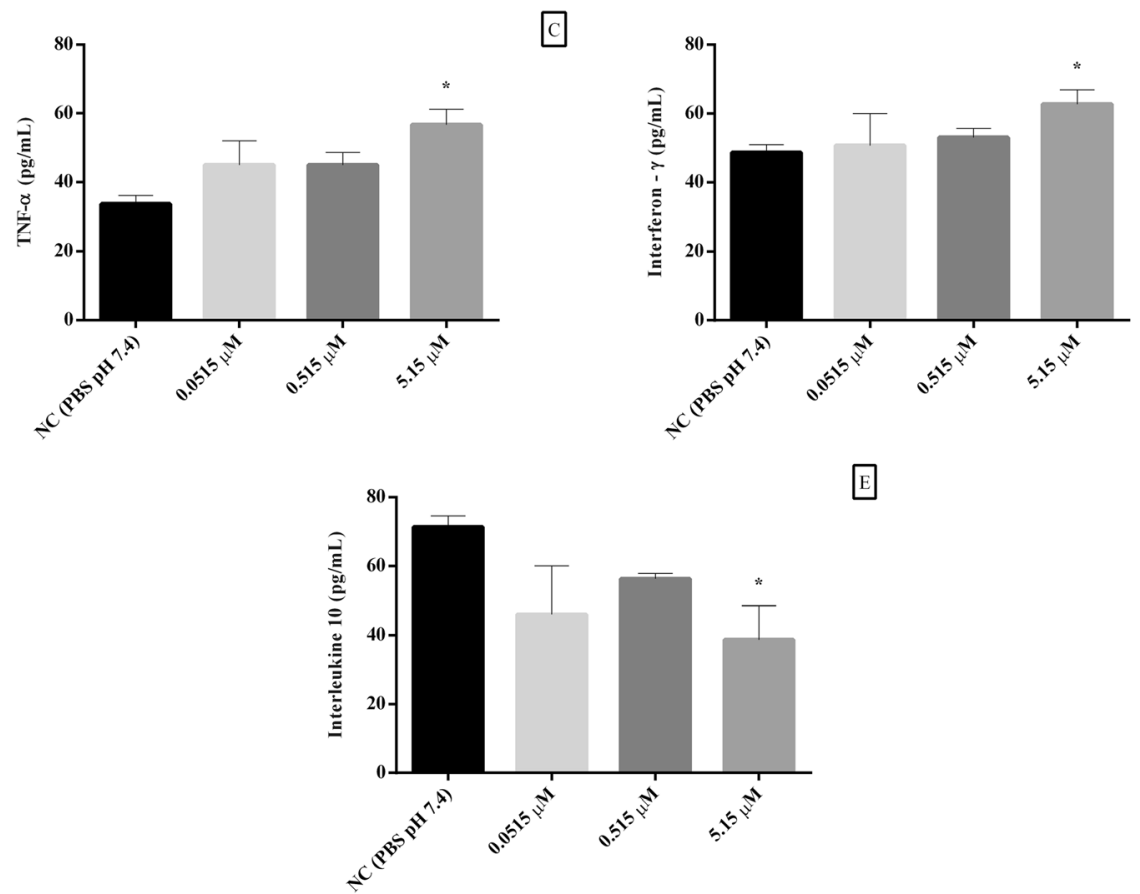

Fig. 3 The cytokine levels (IL-1 (a), IL-6 (b), TNF- $a(\mathbf{c})$, IFN-y (d) and IL-10 (e)) at lymphocytes exposed to different concentrations of $y$-hexalactone. Data were expressed as mean \pm standard deviation, $n=3$, and analyzed by one-way analysis of variance (ANOVA) followed by Bonferroni's post hoc; $\left(^{*}\right)$ represent a statistically significant difference at $p<0.05$ in relation to the negative control (NC)

We must consider that the predictions methods are based on comparative evaluation of test molecules with databases and therefore, they are not always full reliable evaluations, requiring more than one platform for each parameter assayed or experimental validations like those performed here. Thus, the in silico findings can be either a complement or a screening for subsequent tests, but not replace the in vitro or in vivo analysis.

Regarding the genotoxicity, the comet assay revealed significant DNA damage in the lymphocytes exposed to $\gamma$ hexalactone at $5.15 \mu \mathrm{M}$ concentration in comparison with the negative control. Although we have presented in Table 1 only the mutagenicity and carcinogenicity data, the platforms provide additional information, which may be useful in the exploration of mechanisms of action. In our study, DNA damage may be related to the prooxidant status of $\gamma$-hexalactone defined by the presence of two electron accepting sites in its structure according to the pKCSM platform. The ability to accept electrons generates reactive species that may be involved in the initiation and propagation of chain reactions with macromolecules and consequent cell damage [11, 20]. Sinha and co-workers demonstrated that higher than $25 \mu \mathrm{g} / \mathrm{mL}$ concentration of citral, a flavoring widely used in food, also induced genotoxicity in human lymphocytes [11]. Further, the DNA damage may be connected to the carcinogenic potential indicated by computational analysis (PreADMET).

Cytokines such as IL-1, IL-6, TNF- $\alpha$, IFN- $\gamma$, and IL-10 are biomarkers to assess the immune cell function because their production or secretion are linked to activation, differentiation, inflammatory, and apoptosis in immune system responses [21]. In our experiments, we 
observed that $\gamma$-hexalactone modulates the lymphocytes cytokines, increasing the IL-1, IL- 6 , TNF $\alpha$, and IFN- $\gamma$ levels, while decreasing the IL-10 levels. Here, although cytokines (combined results) pointed out to an inflammatory effect, we unobserved an increasing in cell death. This phenomenon could be associated with the tested concentrations, since it was able to induce an increasing in cytokines levels, but still insufficient to cause death in tested cells (non-cytotoxic concentrations). This modulatory profile may be helpful in inflammatory conditions or in response against pathogens and tumors. However, in physiological condition, it could set an imbalance on immune system homeostasis inducing allergic events $[22,23]$. Furthermore, this increase in secretion of proinflammatory cytokines could be promoting the DNA damage observed in our study. In fact, according to Bastos et al. 2017, inflammatory responses against infection or tissue injury could promote DNA damage in the form of chromosomal fragmentation, mutations points, and the formation of DNA adducts [24].

We suggest that the immunoregulatory effect can be promoted by NK cell activation according as demonstrate for Chen et al. 2006 in their study with $\gamma$ - dodecalactone, which presents a similar chemical structure to $\gamma$-hexalactone. Nonetheless, complementary in vitro and in vivo investigations on immunological biomarkers could help us to validate the results and confirm the impact these data on immune system [25]. Thus, although the use of this flavoring is permitted, it is necessary to develop more studies to establish its safe concentrations mainly such as food flavoring $[21,22,26]$.

\section{Conclusion}

We have shown for the first time that $\gamma$-hexalactone has immunomodulatory potential and causes DNA damage in human lymphocyte at non-cytotoxic concentrations. Further studies should be performed to confirm the proposed mechanisms and to define the of safe concentrations range for use in food.

\begin{abstract}
Abbreviations
ANOVA: One-way analysis of variance; NC: negative control; FAO: Food and Agriculture Organization; FBS: Fetal bovine serum; $\mathrm{I}_{50}$ : 50\% cell-growth inhibition; JECFA: Joint FAO/WHO Expert Committee on Food Additives; PBMC: Peripheral blood mononuclear cells; PBS: Phosphate buffered saline; PHA-M: Phytohemagglutinin-M; WHO: World Health Organization
\end{abstract}

\section{Acknowledgments}

The authors gratefully acknowledge the support of Grupo de Pesquisa em Toxicologia Celular (TOXCEL) and Grupo de Estudos em Estresse Oxidativo (GESTOX) both from Universidade Federal do Pampa by the fundamental aid in the accomplishment of the experiments.

\section{About this supplement}

This article has been published as part of BMC Pharmacology and Toxicology Volume 20 Supplement 1, 2019: Proceedings of Toxi-Latin 2018. The full contents of the supplement are available online at https:/bmcpharmacoltoxicol. biomedcentral.com/articles/supplements/volume-20-supplement-1.

\section{Authors' contributions}

All authors have made substantial contributions to the conception, design, analysis, and the interpretation of this research article. Specifically, VM, LFSO and MMM designed research; LZ, TAE, QDFA and EGS conducted research and analyzed data; TD and MMMFD were responsible for ELISA immunoassay; LZ and FRP conducted in silico evaluations, LZ, MMM and LFSO wrote the paper. All authors have been involved in the critical revision of this version of the manuscript regarding important intellectual content. and approved this present version.

\section{Funding}

This research did not receive any specific grant from funding agencies in the public, commercial, or not-for-profit sectors. Publication costs are funded by the authors.

\section{Availability of data and materials}

All data generated or analyzed during this study are included in this published article.

\section{Ethics approval and consent to participate}

This study was approved by Ethics Committee of Universidade Federal do Pampa under the $\mathrm{n}^{\circ}$ 27045614.0.0000.5323. The Committee waived signature of the informed consent form by the volunteers, since the collected blood was used exclusively as a source of cells for the experiment, posing no risk to the donor.

\section{Consent for publication}

Not applicable.

\section{Competing interests}

The authors declare that they have no competing interests.

\section{Author details}

'Programa de Pós-Graduação em Bioquímica, Universidade Federal do Pampa, Uruguaiana, Brazil. ${ }^{2}$ Curso de Farmácia, Universidade Federal do Pampa, Uruguaiana, Brazil. ${ }^{3}$ Programa de Pós-Graduação em Ciências Farmacêuticas, Universidade Federal do Pampa, Uruguaiana, Brazil. ${ }^{4}$ Programa de Pós-Graduação em Farmacologia, Centro de Ciências da Saúde, Universidade Federal de Santa Maria, Santa Maria, Brazil.

${ }^{5}$ Universidade Luterana do Brasil, Santa Maria, Brazil.

Published: 19 December 2019

\section{References}

1. Adams T, Greer D, Doull J, Munro I, Newberne P, Portoghese P, Smith R, Wagner B, Weil C, Woods L. The FEMA GRAS assessment of lactones used as flavour ingredients. Food Chem Toxicol. 1998;36:249-78. https://doi.org/10. 1016/S0278-6915(97)00163-4.

2. He F, Farbood MI, Kizer LE. Process for preparing GAMM-hexalactone, products produced therefrom dan organoleptic uses of said products. In: book process for preparing GAMM-hexalactone, products produced therefrom dan organoleptic uses of said products. City: Google Patents; 2000.

3. Joint FAO \& WHO Expert Committee on Food Additives: Forty-ninth Meeting of the Joint FAO/WHO Expert Committee on Food Additives. Safety Evaluation of Certain Food Additives and Contaminants in Food: Aflatoxins. 1998:359-469.

4. Cheng F, Li W, Zhou Y, Shen J, Wu Z, Liu G, Lee PW, Tang Y. admetSAR: a comprehensive source and free tool for assessment of chemical ADMET properties. In: book admetSAR: a comprehensive source and free tool for assessment of chemical ADMET properties. City: ACS Publications; 2012.

5. Sander T. OSIRIS property explorer. Organic Chemistry Portal. 2001.

6. Pires DE, Blundell TL, Ascher DB. pkCSM: predicting small-molecule pharmacokinetic and toxicity properties using graph-based signatures. J. Med Chem. 2015;58:4066-72. https://doi.org/10.1021/acs.jmedchem.5b00104.

7. Lee S, Chang G, Lee I, Chung J, Sung K, No K. The PreADME: pc-based program for batch prediction of adme properties. EuroQSAR. 2004;9:5-10.

8. Machado MM, de Oliveira LF, Zuravski L, ROd S, Fischer P, Duarte JA, Rocha MO, Güez CM, Boligon AA, Athayde ML. Evaluation of genotoxic and cytotoxic effects of hydroalcoholic extract of Euphorbia tirucalli (Euphorbiaceae) in cell cultures of human leukocytes. An Acad Bras Cienc. 2016;88:17-28. https://doi.org/10.1590/0001-3765201520140076. 
9. Joint FAO. Evaluation of certain food additives and contaminants. Fortyninth report. Technical report series 884. Geneva: WHO; 1999.

10. Burow ME, Weldon CB, Tang Y, Navar GL, Krajewski S, Reed JC, Hammond TG, Clejan S, Beckman BS. Differences in susceptibility to tumor necrosis factor a-induced apoptosis among MCF-7 breast cancer cell variants. Cancer Res. 1998:58:4940-6.

11. Sinha S, Jothiramajayam M, Ghosh M, Mukherjee A. Evaluation of toxicity of essential oils palmarosa, citronella, lemongrass and vetiver in human lymphocytes. Food Chem Toxicol. 2014;68:71-7. https://doi.org/10.1016/jfct. 2014.02.036.

12. Bułdak Ł, Łabuzek K, Bułdak RJ, Kozłowski M, Machnik G, Liber S, Suchy D, Duława-Bułdak A, Okopień B. Metformin affects macrophages' phenotype and improves the activity of glutathione peroxidase, superoxide dismutase, catalase and decreases malondialdehyde concentration in a partially AMPKindependent manner in LPS-stimulated human monocytes/macrophages. Pharmacol Rep. 2014;66:418-29. https://doi.org/10.1016/j.pharep.2013.11.008.

13. Freysdottir J, Logadottir OT, Omarsdottir SS, Vikingsson A, Hardardottir I. A polysaccharide fraction from Achillea millefolium increases cytokine secretion and reduces activation of Akt, ERK and NF-KB in THP-1 monocytes. Carbohydr Polym. 2016;143:131-8. https://doi.org/10.1016/j.carbpol.2016.02.017.

14. Schmid W. The micronucleus test. Mutat Res. 1975;31:9-15.

15. Singh NP, McCoy MT, Tice RR, Schneider EL. A simple technique for quantitation of low levels of DNA damage in individual cells. Exp Cell Res. 1988;175:184-91. https://doi.org/10.1016/0014-4827(88)90265-0.

16. Montano MAE, da Cruz IBM, Duarte MMMF, da Costa KC, Mânica-Cattani MF, Soares FAA, Rosa G, Maris AF, Battiston FG, Trott A, Lera JPB. Inflammatory cytokines in vitro production are associated with Ala16Val superoxide dismutase gene polymorphism of peripheral blood mononuclear cells. Cytokine. 2012;60:30-3. https://doi.org/10.1016/j.cyto.2012.05.022.

17. Prism G. Graphpad software. CA, USA: San Diego; 1994.

18. Eisenbrand G, Pool-Zobel B, Baker V, Balls M, Blaauboer B, Boobis A, Carere A, Kevekordes S. J-C Lhuguenot, Pieters R, Kleiner J. methods of in vitro toxicology. Food Chem Toxicol. 2002;40(2-3):193-236. https://doi.org/10 1016/S0278-6915(01)00118-1.

19. Salgueiro ACF, Folmer V, da Rosa HS, Costa MT, Boligon AA, Paula FR, Roos $\mathrm{DH}$, Puntel GO. In vitro and in silico antioxidant and toxicological activities of Achyrocline satureioides. J Ethnopharmacol. 2016;194:6-14. https://doi.org/10. 1016/j.jep.2016.08.048.

20. Riley PA. Free radicals in biology: oxidative stress and the effects of ionizing radiation. Int J Radiat Biol. 1994;65:27-33. https://doi.org/10.1080/ 09553009414550041.

21. Yadav A, Kumar A, Das M, Tripathi A. Sodium benzoate, a food preservative, affects the functional and activation status of splenocytes at non cytotoxic dose. Food Chem Toxicol. 2016;88:40-7. https://doi.org/10.1016/.fct.2015.12.016.

22. Maier E, Kurz K, Jenny M, Schennach H, Ueberall F, Fuchs D. Food preservatives sodium benzoate and propionic acid and colorant curcumin suppress Th1-type immune response in vitro. Food Chem Toxicol. 2010;48: 1950-6. https://doi.org/10.1016/j.fct.2010.04.042.

23. Schrey AK, Nickel-Seeber J, Drwal MN, Zwicker P, Schultze N, Haertel B, Preissner R. Computational prediction of immune cell cytotoxicity. Food Chem Toxicol. 2017;107:150-66. https://doi.org/10.1016/j.fct.2017.05.041.

24. Bastos V, Duarte I, Santos C, Oliveira H. Genotoxicity of citrate-coated silver nanoparticles to human keratinocytes assessed by the comet assay and cytokinesis blocked micronucleus assay. Environ Sci Pollut Res Int. 2017;24: 5039-48.

25. Chen C-J, Che Tsai C, Hsieh J-F, Michael Chien C, Wu T-H, Chen S-T. A screening platform for compounds with potential immuno-regulatory activities using human cord blood mononuclear cells. Comb Chem High Throughput Screen. 2006;9:777-84. https://doi.org/10.2174/ 138620706779026033.

26. Carvalho FR, Moura AG, Rodrigues GF, Nunes NM, Lima DJ, Pessoa C, Costa MP, Ferreira PM, Peron AP. Are salty liquid food flavorings in vitro antitumor substances? An Acad Bras Cienc. 2016;88:1419-30. https://doi.org/10.1590/ 0001-3765201620150553

\section{Publisher's Note}

Springer Nature remains neutral with regard to jurisdictional claims in published maps and institutional affiliations.

\section{Ready to submit your research? Choose BMC and benefit from}

- fast, convenient online submission

- thorough peer review by experienced researchers in your field

- rapid publication on acceptance

- support for research data, including large and complex data types

- gold Open Access which fosters wider collaboration and increased citations

- maximum visibility for your research: over $100 \mathrm{M}$ website views per year

At BMC, research is always in progress.

Learn more biomedcentral.com/submissions 